\title{
PRAKSIS ISLAM DALAM MERETAS KEADABAN INDONESIA MULTIKULTURAL.
}

\author{
Achmad Fauzi \\ Pengadilan Agama Kotabaru, Kalimantan Selatan, \\ Email: suhuf_esoterika@yahoo.com
}

\section{Abstract}

This paber discusses the bistoriaity of Islam and state relations, diversity of views among Muslim traditionalists and modernists on the relation of Islam and the state, and ideal configuration of the relation of Islam and the state. By mapping analysis of contemporary-crucial cases, it is found the need to reposition of the state as a facilitator of religious life by taking part religion in all aspects of civic life.

مستيخلص

هذه المقالة تصِف حكميةً شربعِة الاسلام في تحكيم العام بإنلنسية. يستعهِل مصنتف وجةَ

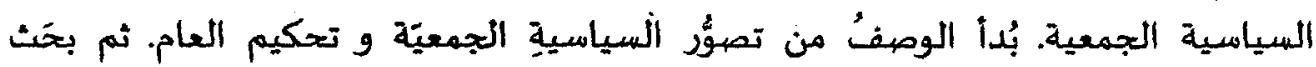

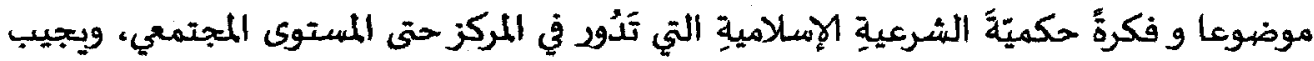

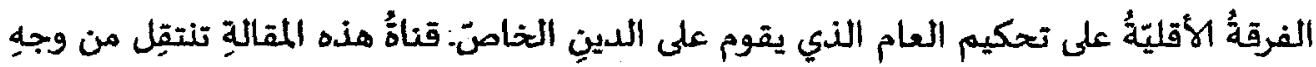
السياسية الجمعية على المسالْة المبحثة وتُنتَهى بالإختتام.

Keywords: Keadaban, Multikultural, Konflik SARA, Pluralisme

\section{A. Pendahuluan}

Jagat kebudayaan yang menjadi penopang bangunan keadaban Indonesia sejatinya telah lama mengakar sebagai khazanah keunikan bangsa. Betapapun 
dalamnya menggali Indonesia, di lapisan dasar tersimpan benih unggul yang kelak menumbuhkan identitas kultural bangsa. Benih yang disemai keterpanggilan batin komunitas warga untuk merajut labirin kesadaran dalam wadah kebangsaan. Itulah kemilau khazanah suku, agama, ras dan antargolongan.

Semesta interpretasi jati diri Indonesia secara alamiah tidak bisa dipisahkan dari karakter majemuk dalam aspek suku, ras, agama dan antar-golongan. Sebaliknya pembicaraan tentang SARA dalam konteks kekinian selalu terkait dengan pendekatan metodologis dan rumusan-rumusan yang menggambarkan masa depan pluralisme di Indonesia.

SARA dan masa depan Indonesia serupa bayi dalam rahim. Tatkala esensi SARA dihakimi dan dipersepsikan sebagai benalu kebangsaan, maka pada saat itulah kita akan menemukan gambaran tentang induk ayam yang mengerami telur busuknya. SARA sebagai yang melahirkan Indonesia tidak akan mampu menetaskan spirit individu baru yang membawa kehidupan bangsa Indonesia menjadi lebih baik.

Kebanggaan negeri dengan cita rasa masyarakat yang majemuk kini mulai terdegradasi. Nilai-nilai multikulturalisme yang pada mulanya merekatkan berbagai lapisan masyarakat dalam ikatan kebinekaan terlepas dari sendisendinya. Konflik antarsukü, antargolongan maupun kelompok politik, serta kekerasan agama yang terjadi belakangan ini telah meruntuhkan nilai pemahaman atas jatidiri SARA. Kemajemukan yang idealnya menjadi energi sentripetal, menjelma menjadi kekuatan sentrifugal yang memecah-belah persatuan. Dapat dikatakan bahwa bangunan keadaban Indonesia tengah berada di tubir jurang kehancuran.

Penggambaran tentang keutuhan dan imunitas masyarakat kita saat ini tak ubahnya daun keting di padang tandus. Ia mudah dikumpulkan tetapi susah diikat. Di samping gampang disulut, sumbunya juga pendek sehingga mudah meledak dan terhambur. ${ }^{1}$ Negara yang diharapkan menjadi rumah yang teduh bagi keberlangsungan hidup segenap anak bangsa, justru menggiring warganya

1 Achmad Fauzi, "Robohnya Keadaban Kita", Harian Kompas, 17 September 2011.hal.6. 
dalam jebakan api pertikaian. Padahal pluralisme adalah cikal bakal berdirinya Indonesia. Pluralisme seperti "rahim" yang telah melahirkan Indonesia.

Islam sebagai agama yang menjunjung tinggi kepelbagaian ditantang untuk menjawab persoalan kebangsaan itu. Konsep tasamub (toleran), tawazun (seimbang), tawasutb (moderat), dan tasyawur (dialog) merupakan ajaran pokok Islam dalam membangun kontak kultural yang tidak hanya menetaskan toleransi dan pengakuan eksistensi kebudayaan yang bercorak plural, tapi juga menumbuhkan saling pengaruh dan memperkaya gagasan multikulturalisme. Gagasan multikulturalisme itu akan mempertemukan segenap kenyataan bahwa sejatinya hakikat seseorang, komunitas kebudayaan maupun agama terbangun dari unsur kebudayaan yang beraneka ragam. Sehingga dalam diri kita hidup asa orang lain dan dalam diri orang lain tersimpan harapan kita. Bahwa kita dan orang lain tidak pernah berserak, seperti ruh dalam wadag. Karena itu jika orang lain menjadi korban kebiadaban dan kebengisan manusia, batin kita turut merasakan penderitaan itu. Ajaran pokok itu tentunya dapat diterapkan dengan bertitik tumpu pada kesadaran untuk mengatur kehidupan sepadan dengan kenyataan tentang pluralisme peradaban, budaya, dan agama. Bagaimana bisa dikembangkan sebuah kehidupan yang penuh respek antara satu dengan yang lain, sehingga kepelbagaian benar-benar menjadi berkah bagi semua orang dan bukan menjadi laknat dan petaka bagi kehidupan.

\section{B. Ke(bi)adaban Umat Beragama Kini}

Tiang penyangga keadaban Indonesia saat ini mengalami pengeroposan dalam banyak sisi. Situasi batin umat beragama berada dalam kondisi labil. Konflik silang sengkarut berdasarkan sentimen agama kerap menghantui kita. Jika para tokoh agama mengklaim komunikasi antar-pemimpin agama telah membaik, itu tidak keliru. Tapi jejaring soliditas antaragama pada tatatan akar rumput harus diakui masih rapuh karena intensitas perjumpaan minim. Dialog lintas agama hanya berlangsung di tingkat elite, sedangkan basis gerakan masyarakat bawah dalam menciptakan kerukunan nihil. Wajat jika hubungan antaragama di akar rumput masih berjalan tertutup dan sarat prasangka. 
Benih prasangka dan kebencian antar-umat beragama terus mengalami kristalisasi sehingga memandang otang lain sebagai "liyan". Relasi divergen sosial-keagamaan tidak berkembang dengan baik. Semua itu bermuara pada klaim keagamaan yang eksklusif. Selama ini hambatan primordial untuk mencintai sesama adalah egoisme keagamaan. Kepentingan diri membuat orang memberi tanpa ketulusan. Kepentingan diri membuat kita melihat sesama anak bangsa sebagai musuh yang harus diperangi. Cinta kasih mustahil tumbuh dalam lingkungan keserbalainan. Acapkali kita melihat ironi. Dengan dalih membela kebenaran, menegakkan keadilan, membangun demokrasi, menjaga HAM aćau mencintai agama, kebencian berusaha mendorong tindak keketasan yang seolah mendapat pembenaran, tetapi berakibat amat memilukan.

Ancaman nyata proses melestarikan keadaban yang toleran adalah mengakarnya fundamentalisme agama. Kekerasan dengan berbagai variabelnya belakangan ini susul-menyusul tak ubahnya petasan menjelang lebaran. Sialnya, negara tidak berdaya memotong sumbu kekerasan yang percikannya bisa memantik kekerasan baru yang lebih dahsyat. Akhirnya masyarakat mengalami "latah" dan menjadikan kekerasan sebagai tren baru dalam mempertahankan klaim kebenaran. Sebut saja nalar kekerasan berbentuk böm di Gereja Bethel Injil Sepenuh, Kepunton, Jebres, Surakarta, Jawa Tengah (25/9/2011). Rasa kemanusiaan kita dirobek oleh bom bunuh diri yang pelakunya diduga laki-laki berumur 30 tahun, memakai baju putih, celana panjang warna hitam, dan memakai sepatu kets. Kutukan dan kecaman datang mengalir dari betbagai tokoh lintas agama, pemerintah, dan masyarakat yang masih menjunjung tinggi nilai keindonesiaan. Tindakan itu dikutuk katena tidak ada ruang yang layak bagi masyarakat Indonesia yang selama ini dikenal ramah, religius dan toleran.

Dalam kitab suci manapun tidak ada legitimasi yang membenarkan tindakan biadab itu. Bagaimana mungkin ada jalan terang menuju surga yang ditempuh dengan cara keji dan biadab. Siapa yang menciptakan "neraka" bagi sesamanya selama di dunia, kelak akan merasakan kejamnya neraka yang sesungguhnya.

Bom bunub diri di dalam gereja di Solo yang melanggar etika kemanusiaan merupakan eksternalisasi dari sikap kebencian dan egoisme. Kebencian 
mengeliminasi cinta kasih terhadap sesama anak bangsa. Kebencian menjadikan Indonesia sebagai tempat yang gersang bagi berlangsungnya kepelbagaian dalam ikatan kebinekaan. Kebencian membuat orang yang berlainan ideologi halal darahnya, sehingga sah untuk diperangi. Kebencian membuat relasi antarmanusia dipenuhi kecurigaan atau prasangka.

Bom bunuh diri terhadap kelompok lain dengan mengatasnamakan agama seringkali menimbulkan permusuhan yang sangat keras, ribuan kali lebih keras. Demi pembelaan terhadap agama, seseorang melupakan sifat kemanusiaannya. Almarhum Abdurrahman Wahid (Gusdur) menulis bahwa banyak sekali orang menganggap agama sama dengan Tuhan, padahal agama bukan Tuhan. Orang menganggap membela agama sama halnya dengan membela Tuhan. Padahal, Tuhan tidak perlu dibela, sebaliknya Tuhan membela manusia yang diciptakan. ${ }^{2}$ , Masalah terorisme erat kaitannya dengan pendangkalan pemahaman agama. Paradigma jihad dalam agama selalu final di genangan darah kekerasan. Orang dianggap halal untuk dibunuh manakala memiliki pemahaman berbeda. Pemaknaan yang simplistis in jika tidak dicerahkan akan melahirkan kekerasan dalam agama. Di sinilah tugas tokoh agama Islam untuk memberikan pemahaman yang benar tentang pesan profetis agama. Tugas pokok tokoh agama Islam adalah mewartakan kepada pemeluknya agar pemahaman jihad dalam agama tialak dibajak oleh arogansi kelompok teroris. Pesantren sebagai basis pendidikan agama selayaknya menjadi pelopor lahirnya teologi inklusif. Bukan sebagai tempat bersemainya radikalisme, eksklusivisme yang menafsir jihad dalam kacamata kekerasan belaka dan menutup diri dari budaya luar. Memaknai jihad akbar sesungguhnya berakar pada kemampuan diri untuk menahan amarah dan melawan hawa nafsu yang di dalamnya mengandung kebencian.

Ancaman berikutnya yang turut mendorong robohnya keadaban kita adalah konflik horizontal bermuatan sentimen agama. Sepanjang tahun 2011 ditayangkan secara gamblang betapa potret kebebasan beragama berwajah kelam. Berbagai aksi kekerasan dan praktik intoleransi di sepanjang tahun ini semakin menguat. Konflik berdasarkan sentimen agama, pemberangusan

${ }^{2}$ Abdurrahman Wahid, Tuban Tidak Perlu Dibela, (Yogyakarta: LKiS, 1999), hal.20. 
tempat ibadah dan penyerangan kelompok yang dianggap sesat adalah deret persoalan yang membuat peta pluralisme semakin buram.

Di akhir tahun 2011 The Wahid Institute merilis laporan tentang kebebasan beragama dan berkeyakinan (KBB) di Indonesia. Berdasarkan deret angka pelanggaran $\mathrm{KBB}$ dan intoleransi yang didata, terjadi kenaikan $18 \%$ dari yang sebelumnya 64 kasus (tahun 2010) menjadi 92 kasus (tahun 2011). Dari 92 kasus pelanggaran $\mathrm{KBB}$, Jemaat Ahmadiyah sebagai yang terbanyak menjadi korban, disusul jemaat GKI Yasmin, Bogor. ${ }^{3}$

Sejatinya upaya penyegelan, pembubaran dan pemberangusan Ahmadiyah inkonstitusional, karena negara telah mengingkari kewajibannya dalam melindungi, menghormati, memajukan dan menegakkan hak asasi warga negaranya, sebagaimana diamanatkan oleh pasal 71 dan 72 UU No. 39 tahun 1999 tentang Hak Asasi Manusia. Dorongan pembubaran tidak bersandar pada kesadaran bahwa dalam menjalankan imannya, manusia tidak bisa diseragamkan. Pasal 28 E ayat (1) dan (2) UUD 1945 dengan jelas memberikan ruang kebebasan bagi setiap orang untuk memeluk agama dan berhak atas kebebasan meyakini kepercayaan. Agama adalah hak fundamental manusia. Menganut atau tidak suatu agama, meyakini atau tidak suatu kepercayaan adalah hak seseorang secara pribadi yang melekat pada harkat dan martabatnja sebagai manusia. Jika pembubaran itu tetap dilakukan, berarti pemerintah ikut mendorong masyarakat untuk memilih agama yang bertentangan dengan keyakinan nurani.

Sejarah panjang penghakiman terhadap perbedaan agama dan keyakinan yang kerap diwarnai dengan pertumpahan darah memang tak mengenal kata tamat. Estafet kekerasan dan invasi iman terus direproduksi dan diamini kelompok di setiap era sebagai pilihan pragmatis meneguhkan dominasi. ${ }^{4}$ Jika

${ }^{3}$ Loporan Kebebasan Beragama 2011 The Wabid Institute, dikutip dari http://www.wahidinstitute.org/Dokumen/Detail/?id=184/hl=id/Laporan_Kebebasan_Berag ama_2011_The_Wahid_Institute. Diakses 11 Januari 2012.

${ }^{4}$ Contoh paling menarik ihwal penghakiman iman seperti dalam sejarah Syekh Siti Jenar yang dipenggal mati usai shalat Jum'at di hadapan para wali dan pembesar istana lantaran dianggap melawan kekuasaan para ulama yang mengunggulkan ortodoksi. Cerita dari Baghdad pada abad X mengatakan bahwa darah Jenar muncrat membentuk 84 tetes dan menulis kata "Allah". Sepotong kepala yang lepas dari tubuhnya itu, lantas tertawa sembari berseru agar 
demikian tidak keliru manusia dipersepsikan sosok yang ambisius memperebutkan wilayah dominasi, termasuk dominasi keagamaan. Peristiwa mutakhir terkait invasi iman dan pemberangusan atas nama agama datang dari Kabupaten Sampang, Madura. Sebagai masyarakat yang dikenal santri, tentu penyerangan dan pembakaran rumah maupun pondok pesantren milik kelompok Syiah di Kecamatan Omben, Sampang, Madura menjadi ironi dan tanda tanya banyak orang. Pasalnya, ketika almarhum Abdurrahman Wahid (Gusdur) masih hidup, Madura menjadi basis Nahdatul Ulama dengan tingkat penghargaan dan toleransi yang tinggi terhadap isu keragaman. Gus Dur tidak saja berhasil menanamkan kultur damai terhadap sesama dan inklusif dalam berteologi, tetapi juga tegas melindungi kaum minoritas dengan mengerahkan pengikutnya untuk melakukan penghadargan bagi kelompok radikal yang akan melakukan penyerangan. ${ }^{5}$

Keyakinan kepada Tuhan Yang Maha Esa secara intuitif tidak bisa dipaksakan, terlebih ditundukkan oleh kekuasaan. Iman merupakan hasil pencarian, tidak sekadar melalui ketajaman logika yang bisa dijawab dengan hitung-hitungan rumus atau dijabarkan dalam kaidah hukum. Tatkala keyakinan dipaksa homogen mengikut mainstream melalui pemaksaan struktural maka agama akan kehilangan semangat profetisnya, sebagai yang membebaskan dari keterkungkungan dan bentuk penindasan lainnya. Oleh karena itu, kasus kekerasan terhadap kelompok yang dianggap sesat yang terjadi secara berulangulang hendaknya tidak dikaji dari satu perspektif saja. Karena dampak pembatasan kebebasan beragama itu secara linear akan memicu simpati kelompok radikal untuk memorakporandakan stabilitas kesatuan dan persatuan kita. Dimensi-dimensi lain seperti kegagalan pemerintah mengelola modernisasi dan globalisasi harus ditanggapi secara demokratis dengan memberi kesempatan untuk hidup bagi kelompok-kelompok kecil dan lemah. Proses demokratisasi harus dimulai dengan dialog yang terbuka dan fair antar komponen pluralisme.

darahnya segera kembali ke tubuh, sehingga bercak darah tidak tampak lagi. Peristiwa itu menjadi pertanda bahwa barangsiapa yang menghukum mati seseorang karena iman dan pendirian akan mendengar sepotong kepala yang tertawa.

${ }^{5}$ Achmad Fauzi, "Syiah Sampang Versus Syiar Kebencian". Koran Tempo, 6 Januari 2012, hal . A 11. 
Selama ini bangunan keharmonisan antarumat beragama berjalan rumit karena tereduksi oleh pengaturan formal negara. Negara, sebagai yang menguasai wilayah dominasi, terlalu gegabah melakukan kebijakan kontrol yang sangat ketat, sehingga minoritas suka atau tidak suka harus tunduk kepada kepentingan penguasa. Tidak ada pendewasaan (maturation) dan pemberdayaan (empowerment) individu dalam cara beragama karena politik survailence oleh negara telah melumpuhkan peluang agama untuk mengembangkan landasan etik bagi dirinya. Sekat-sekat aturan yang sangat teknis itu, juga membatasi ruang nafas bagi masyaralaat sipil untuk terlibat aktif dalam mengatur, utamanya mengenai interaksi umat beragama, sehingga mereka kehilangan kapasitas yang dalam jangka panjang melemahkan tingkat keberdayaannya.

Lihat saja kesan yang muncul, misalnya, pasca diterbitkannya Surat Keputusan Gubernur di beberapa daerah tentang pelarangan aktivitas Jemaat Ahmadiyah. Tokoh dan pemuka agama di mata masyarakat terkesan tidak berdaya dalam mengelola bidang tugasnya, sehingga perlu meminjam tangan pemerintah. Di samping itu, umat beragama terkesan terkotak-kotak lantaran adanya batasan-batasan peraturan yang parsial.

Pengaturan persoalan Ahmadiyah idealnya menjadi wilayah agama dengan lebih menekankan ikatan kultural daripada regulasi formal. Sedangkan pemerintah lebih baik berupaya menciptakan penegakan hukum yang serius terhadap pelaku kekerasan berbasis agama. Selama ini penilaian kinerja aparatur hukum menunjukkan ketidakpuasan terhadap kinerja aparat peradilan dalam menangani kasus kekerasan berbasis agama. Ketidakpuasan itu tercermin, misalnya, dari vonis bebas maupun hukuman ringan yang dijatuhkan kepada pelaku kekerasan terhadap Ahmadiyah di Cikeusik. Alih-alih memberikan efek jera, kondisi supremasi hukum yang tapuh itu justru dimanfaatkan kelompok tertentu untuk merusak suasana kebatinan berbangsa demi merebut wilayah dominasi.

Pokok penting lainnya terkait semakin rapuhnya keadaban masyarakat kita lantaran negara mandul dan kebijakan yang digulirkan banyak mencederai kelompok minoritas. Ketidakberdayaan peran negara itu ditandai oleh beberapa indikator, misalnya, ketidakhadiran peran negara saat minoritas menjadi bulan- 
bulanan dalam pusaran konflik horizontal, kegagalan negara dalam mengelola modernisasi dan globalisasi yang berdampak pada minimnya kesempatan untuk hidup bagi kelompok-kelompok kecil dan lemah, serta pengabaian hak-hak konstitusional minoritas sebagai kelompok yang tidak diuntungkan dalam struktur sosial, yang kesemuanya menjadi wujud dari peran negara yang inkonstitusional. Mendambakan kedamaian di Indonesia tanpa memberikan jaminan konstitusional terhadap setiap warga adalah sesuatu yang keliru. Seharusnya, jaminan itu menjadi hak setiap warga tanpa membeda-bedakan. Kadangkala minoritas dianaktirikan karena dianggap tidak mampu melanggengkan kekuasaan.

Alih-alih negara melakukan definisi ulang tentang fungsi dan perannya dalam menciptakan masyarakat berkeadaban, masyarakat justru disuguhi perilaku kaum elit yang tunamalu. Setiap hari masyarakat disuguhkan oleh lakon elit politik yang tanpa malu melakukan korupsi, menjarah uang rakyat, membunuh rakyat dengan data, melakukan politik pencitraan dan mengabaikan keselamatan bangsa. Keadaan ini semakin membuat kohesi sosial antarmasyarakat terurai dari sendi-sendinya.

Persepsi keragaman berbentuk suku, agama, ras dan antargolongan kini masih pejoratif dan belum absen dari kultur politik kolonial yang segregatif. "Eer gevoel" adalah term populer dalam sejarah kolonial yang bermakna agama atau suku yang satu lebih unggul dan mulia dari yang lain. Bekerjanya kendali politik rezim atas kemajemukan membuat keberdayaan komunitas warga dalam mewujudkan kehildupañ demokratis, setara dan kooperatif lemah digantîkan peran negara dalam setiap sektor kehidupan.

Terus terang masyarakat mulai kesulitan mencari sosok negarawan yang bisa mengayomi kepentingan semua suku, agama, ras dan antar golongan (SARA) dalam rumah betsama bernama Indonesia. Kepentingan rakyat terabaikan, sehingga imunitas masyatakat atas hasutan pemangku kepentingan semakin terkikis dan gampang terlecut. Orang gampang marah dan tersinggung. Isu SARA menjadi umpan kerusuhan paling mujarab. Sensitivitas yang menimbulkan persinggungan masyarakat sipil seperti di Ambon, sipil versus aparat di Mesuji dan Bima, merupakan puncak gunung es dari kefrustasian 
masyarakat terhadap elit politik yang tidak becus mengurus negara. Itu semacam tamparan yang dialamatkan kepada elit negara supaya menyadari betapa rapuhnya rasa kebangsaan masyarakat Indonesia saat ini.

Kaum elit juga bisa melihat bahwa jati diri bangsa berwujud SARA, sehingga membenturkan SARA untuk kepentingan politik pragmatis sebagai hal yang keliru. Mendiang Th. Sumartana menyebut bahwa suku, agama, ras dan antar gologan (SARA) adalah "ibu" yang melahirkan Indonesia. Soekamo, Mohamad Hatta, Tjipto Mangunkusumo, Kwee Thiam Hong, Haji Agus Salim, Raden Sutomo, dan lain-lain adalah putera-puteri terbaik dari "ibu" SARA. Mereka merupakan tokoh yang memiliki karakter majemuk dan tidak pernah membenturkan SARA untuk kepentingan politik. ${ }^{6}$

Intrusi di atas semakin diperparah oleh grafik distribusi ekonomi dan keadilan sosial di setiap daerah yang terjun bebas. Komparasi jaminan kesejahteraan warga dengan takaran upeti untuk negara timpang, sehingga nasionalisme suku kerap berbenturan dengan kebijakan nasionalisme yang berpusat di Jakarta. Bumi, air dan kekayaan yang terkandung di dalamnya seharusnya dikelola untuk kemakmuran bersama, namun nyatanya dieksploitasi asing. Fakta terkini menunjukkan bahwa kedaulatan ekonomi Indonesia $51 \%$ dikuasai oleh asing. Ini ditandai dengan penguasaan sektor strategis seperti keuangan, energi dan sumber daya mineral, telekomunikasi, sehinga Negara Indonesia tersandera dalam mengelola kekayaannya. Oleh karena itu, negara harus menata ulang strategi pembangunan ekonomi agar hasilnya lebih merata dirasakan rakyat. Menangkal potensi disintegrasi akibat gesekan perbedaan suku, ras, dan pemahaman agama yang berbeda, terlebih dahulu dimulai dengan melupakan memori pengalaman manusiawi yang penuh traumatik. ${ }^{7}$ Memori itu sejatinya sulit untuk dilupakan karena tersandera oleh praktik bernegara yang menindas dan nirkeadilan. Karena itu negara harus mereformasi dua peran fundamental, yakni memberikan jaminan konstitusional warga dan meninjau ulang distribusi keadilan dalam segala aspek.

6 Th. Sumartana, dkk, Pluralisme, Konflik dan Pendidikan Agama di Indonesia, ( Yogyakarta: Institute DLAN/Interfidei, 2001), hal.91.

${ }^{7}$ Ibid.,hal.95. 
Persoalan lain mengenai kualitas pelaksanaan otonomi daerah, desentralisasi serta demokratisasi tidak berjalan maksimal. Keadaan ini turut menstimulus munculnya radikalisme kedaerahan. Pergolakan Papua adalah amsal yang perlu dikaji berkait kemungkinan itu. Tatkala terjadi penyempitan kesadaran menghayati diri secara inklusif sebagai entitas bangsa, kemungkinan besar suku-suku di Indonesia terancam bercerai-berai dan mengurus dirinya sendiri secara merdeka. Ini berbahaya. Karena itu, peningkatan kesejahteraan masyarakat di daetah rawan konflik atau separatisme melalui perbaikan akses masyarakat lokal terhadap sumber daya ekonomi dan pemerataan pembangunan antardaerah penting dilakukan.

Kita punya pedoman Pancasila yang paripurna dalam bernegara, tapi tunapengamalan. Sila Persatuan Indonesia dirumuskan bettujuan mengangkat martabat dan kehidupan suku-suku di Indonesia. Dan, wawasan nasional yang sehat meniscayakan sikap menjunjung tinggi kemajemukan dan memperhatikan kepentingan suku yang selama ini terabaikan. Begitupula sila keadilan sosial mewasiatkan pemerataan pembangunan tanpa unsur monopoli dari oligarki politik. Itulah yang seharusnya menjadi pedoman nilai bagi kita agar tidak terlampau tergelincir dari rel kesejahteraan yang dicita-citakan.

\section{Pancasila dan Persaingan Semesta Ideologi}

Sebagian masyarakat kita memandang persoalan kebangsaan saat ini sebagai ganjaran keputusan pendiri negara yang tidak menganut negara Islam sebagaimana diserukan para penganjurnya. Akibatnya Pancasila bukan saja terancam dalam konteks sebagai dasar, tapi juga mengalami reduksi secara ideologis.

Di zaman Orde Baru agama dijadikan instrumen proses legitimasi negara. Namun kini berlaku sebaliknya, negara justru menjadi gelanggang yang diperebutkan oleh semesta politik, ideologi maupun agama. Orang mulai gamang melihat Pancasila sebagai dasar maupun ideologi, meskipun secara filosofis substansi yang terkandung dalam sila Pancasila mampu mewadahi berbagai kepentingan agama, budaya dan semesta politik yang ada. Fakta ini berkontribusi besar bagi terciptanya politik formalis yang bersentral pada 
negara. Setiap kekuatan politik-ideologis maupun agama, melihat agenda merebut negara dan menentukan staatside negara sebagai sesuatu yang mutlak. Akibatnya masyarakat terpecah belah dalam kongsi kepentingan dan bendera yang berbeda.

Jika melihat tarik ulur hubungan antara agama dan negara di Indonesia selama ini, setidaknya ada dua simbiosa yang menonjol. Pertama, intervensi negara terhadap agama dalam bentuk kebijakan-kebijakan politis yang memungkinkan agama berada di bawah bayang-bayang kekuasaan, seperti penyingkiran pelbagai aliran iman yang seharusnya dijamin dan diakui sebagai agama oleh negara. Kedua, keinginan agama untuk mempengaruhi negara sebagaimana euforia para nasionalis Islam saat ini yang "ngotot" melakukan formalisasi syariat Islam demi tercapainya cita-cita pembentukan negara Islam. Padahal menurut hemat penulis, upaya penegakan syariat Islam adalah wujud ketidak berdayaan umat Islam terhadap masalah yang menghimpit mereka. Umat Islam menganggap semua masalah akan selesai manakala syariat Islam dalam penafsirannya yang tekstual dan kolot diterapkan di Indonesia.

Relasi antara agama dan negara ini sebenarnya berakar pada suatu political interest, yakni suatu usaha untuk mengontrol dan mengarahkan jalannya kekuasaan berdasarkan jamaknya kepentingan yang ingin diwujudkan lewat jalur politik. Kedua bentuk hubungan itu senyatanya tidak sesuai dengan konstitusi bangsa Indonesia, karena negara menjamin adanya suatu kehidupan keagamaan bagi masyarakat yang bebas dari monopoli negara, sehingga segala bentuk intervensi negara terhadap kehidupan beragama merupakan bentuk pengkhianatan terhadap Pancasila dan isi UUD 1945. Di lain pihak, agama yang berupaya memaksakan suatu norma apalagi mencoba mengagamakan negara juga merupakan bentuk perlawanan terhadap konstitusi, karena Indonesia bukanlah merupakan negara agama (baca seribu kali). Pengagamaan negara tidak serta merta menyelesaikan permasalahan seperti yang sering diklaim oleh para penganjurnya. Tetapi justru memicu persoalan baru yang semakin pelik pemecahannya. Pertama, apabila salah satu golongan atau agama memaksakan norma agama atau ideologinya dalam kehidupan bernegara, maka golongan atau agama yang lain akan menjadi masyarakat kelas kedua, sehingga mereka merasa 
tidak at bome di negaranya sendiri. Kalaupun Nabi Muhammad pernah menorehkan tinta emas dalam proyeknya membangun Madinah menjadi negara yang civilized di atas corak masyarakat yang heterogen (plural agama, ideologi, suku, dan kepentingan), itu merupakan hasil negosiasi antara nilai-nilai Islam yang universal dengan kondisi lokal masyarakat Madinah. Sehingga meneladani Nabi bukan dari segi harfiahnya, tetapi mengambil semangat dari apa yang telah diupayakannya.

Pancasila, kata Soekamo, merupakan filsafat, bimbingan pikiran dan hasrat yang sedalam-dalamnya, yang di atasnya didirikan negara bernama Indonesia yang merdeka, kekal dan abadi. Pancasila adalah visi bersama yang mendahului berdirinya Indonesia. Jika butir-butir pada setiap sila Pancasila dihayati dan diamalkan dalam tata kehidupan bernegara, bukan tidak mungkin Indonesia jauh lebih maju dibandingkan negara-negara yang mengaku sebagai pelopor Negara Islam.

Mengatasi persoalan kebangsaan yang rumit sebenarnya kita tak perlu terjebak pada paradigma formalistik. Jika umat Islam ingin berkontribusi dalam membangun keadaban publik tak perlu terlebih dahulu mengganti Pancasila dengan ideologi Islam. Amien Rais menulis : 'Islamic state atau Negara Islam tidak ada dalam al-Qu'an maupun dalam al-Sunnah. Tidak ada perintah dalam Islam untuk menegakkan negara Islam. Yang lebih penting adalah selama suatu negara menjalankan etos Islam, kemudian menegakkan keadilan sosial, dan menciptakan suatu masyatakat yang egalitarian yang jauh dari eksploitasi manusia atas manusia maupun eksploitasi golongan atas golongan lain, berarti menurut Islam sudah dipandang sebagai negara yang baik. Apalah artinya suatu negara kalau hanya formalitas yang kosong."8

Pancasila memang bukan agama. Tapi sebagai vision of state yang di dalamnya mengandung ide, nilai dan visi, Pancasila tidak alergi terhadap agama. Sebagai contoh pada sila pertama disebutkan secara eksplisit bahwa Pancasila mengandung visi Ketuhanan Yang Maha Esa. Tafsir atas sila tersebut bertitik

\footnotetext{
${ }^{B}$ Amin Raies, dkk, Tidak Ada Negara Islam (Surat-surat Politik Nurcholish Madjid - M. Roem),
} (Jakarta: Djambatan, 1997), hal. sxiii. 
tumpu pada nilai kesadaran bahwa Indonesia sebagai negara yang religius, sehingga wajib hukumnya negara melindungi, menghormati dan memberikan kebebasan kepada setiap warga untuk memeluk dan menjalankan ibadah sesuai keyakinan agama dan kepercayaannya.

Persoalannya banyak sekali sikap keberagamaan yang justru ambivalen dengan sila ketuhanan, bahkan kontraproduktif dengan sila kemanusiaan yang notabene menjadi muara kebertuhanan. Acapkali butir Pancasila dihayati secara parsial dengan mengagungkan sila ketuhanan, tapi menginjak-injak martabat kemanusiaan. Atas nama Tuhan, manusia dan kemanusiaan menjadi tumbal oleh akal yang pendek, amarah dan egoisme. Ikatan sebangsa apalah artinya bagi mereka jika tidak se-ideologi, se-agama.

Oleh karena itu, mengukur tingkat penghayatan terhadap sila ketuhanan bukan berdasar atribut formal, taat beribadah, rajin memerangi kelompok yang dianggap kafir atau memuja Tuhan setinggi langit. Tapi sejauh mana rasa keterpanggilan diri untuk terlibat langsung dalam proyek kebajikan yang memihak pada tegaknya pilar kebangsaan dan kemanusiaan di muka bumi. Itulah hakikat terdalam dari nilai ketuhanan dan kemanusiaan pada sila Pancasila.

\section{Islam sebagai Tata Nilai dan Gerakan}

Arnold Toynbee (sarjana non-Muslim) mengatakan bahwa Islam sebagai agama yang menjunjung tinggi perbedaan (ras, etnik, agama, budaya, dan peradaban). Kesadaran penghapusan dikotomi ras, budaya dan agama adalah salah satu pencapaian prestasi moral yang ditunjukkan oleh Islam. Dalam dunia kontemporer sering muncul semacam tangis kebutuhan akan kebajikan nilainilai Islam yang toleran. Kekuatan toleransi antar-ras sekarang sedang berjuang habis-habisan dalam suatu pertarungan spiritual yang punya makna penting bagi kemanusiaan. Kekuatan-keuatan itu kemungkinan masih tetap berada di papan atas.

\section{6.}

9. Amold Toynbee , Civilization on Trial, (Oxford: Oxford University Press, 1948), hal.205- 
Pernyataan Amold Toynbee tentu bukan omong kosong. Islam sebagai tata nilai maupun sebagai gerakan keagamaan memiliki makna penting dalam mengejawantahkan konsep toleransi, inklusivisme, dan dialog, khususnya dalam bingkai keindonesiaan. Tapi Islam sebagai tata nilai tentu tidak cukup cepat dalam mengatasi persoalan kritis kebangsaan yang tuna-adab. Dibutuhkan praksis Islam dalam bentuk gerakan sebagai kosakata bergegas. Persoalan keadaban adalah masalah watak pada tingkat individu dan budaya pada tataran publik. Karena itu membangun masyarakat Indonesia yang berperadaban multikultural dibutuhkan kanal pendidikan sebagai proses panjang membangun karakter. Orientasi pendidikan karakter itu mengakomodir nilai-nilai adab seperti inklusivisme, kasih sayang, teposeliro, toleransi, dan semangat menghargai. Pada sekolah majemuk pendidikan karakter meniscayakan interaksi pergaulan yang melampaui kelompok partikularnya. Siswa muslim yang cenderung memilih partner interaksi yang se-kelas, se-agama, se-etnis, sesekolah dibiasakan bergaul dan memperlakukan siapa saja secara setara. Supaya berjalan efektif semua guru harus siap menjadi penghayat nilai dengan memberikan teladan baik bagi anak didiknya. Banyak kasus murid "kencing berlari" karena perilaku guru yang memberikan teladan "kencing berdiri".

Implementasi pendidikan karakter bukan sekadar hafalan kaidah-kaidah atau teori, tapi merelevansikan nilai-nilai normatif yang abstrak dalam agama dengan kondisi sosial; sehingga peserta didik mampu menerjemahkan diri dalam kehidupan masyarakat yang kompleks secara fleksibel tanpa ada ketegangan. Peserta didik dari berbagai kelompok, suku, budaya, agama dan kelas sosial dilatih membaur. Unsur-unsur perekat yang menyatukan batin mereka menjadi katarsis dalam mempelajari prinsip-prinsip hidup bersama di sekolah maupun masyarakat.

Pendeseminasian kesadaran toleransi dan menghargai perbedaan melalui jalur pendidikan di pesantren maupun sekolah umum memiliki prospek terang karena pemahaman itu memberikan dasar-dasar karakter kuat sebagai penopang lahirnya manusia inklusif dan demokratis. Namun konsep toleransi yang diajarkan perlu didasarkan kepada kontekstualitas Indonesia sebagai negara yang memiliki corak kehidupan heterogen. 
Sebagai peralihan dari keluarga kepada masyarakat, kini pesantren maupun sekolah pada umumnya ditantang untuk mengembangkan praktik pendidikan toleransi itu. Anak didik dapat diajak memahami hakikat perbedaan agama yang kadangkala menjadi hambatan teologis dalam membangun pergaulan. Dalam konteks ini, pendidikan bukan sekadar memberikan pemahaman bahwa perbedaan itu sebagai realitas yang niscaya. Perlu ada semangat koeksistensi terhadap agama di luar agama kita. Salah satu penerapannya, misalnya tradisi saling mengunjungi dan mengucapkan selamat kepada teman berbeda agama yang merayakan lebaran. Selama ini orang beranggapan mengucapkan selamat sama halnya membenarkan iman mereka. Padahal kosakata selamat lebaran sebagai ungkapan pertemanan, ikatan ketetanggaan dan kemanusiaan. Ini sebentuk peneguhan keimanan bahwa perjuangan dalam menghayati agama bukan sekadar orang punya agama (to bave religion), melainkan bagaimana orar'g menjadi saleh dan peduli terhadap sesama (being religious). Dalam rangka menghidupkan kembali tradisi terpuji itu, peranan pendidikan agama Islam yang toleran di sekolah sangat dibutuhkan. Bagaimana sekolah dengan berbagai macam atribut keagamaannya mempertimbangkan bersama nilai-nilai mana yang dapat ditanamkan kepada anak didik sehingga sejak dini mereka terbiasa mengembangkan hidup bersama.

Betapa seringnya kita menyaksikan penerapan konsep toleransi di sekolah maupun di masyarakat yang cenderung artifisial. Anak didik hanya dituntut untuk toleransi antara yang satu dengan yang lain tanpa dibarengi dengan kesadaran untuk mengerti dan mempelajari agama lain. Menurut almarhum Abdurrahman Wahid pada pidatonya di Surabaya tanggal 18 Juni 1996, kondisi semacam ini masih rawan konflik, karena tuntutannya hanyalah toleransi, bukan saling mengerti. Sehingga, ketika unsur yang mendamaikan hilang maka konflik yang lebih besar tidak dapat dihindarkan.

Hal serupa juga dilakukan oleh lembaga-lembaga keagamaan yang sering menyelenggarakan dialog dengan mengusung tema toleransi dan tenggang tasa. Namun yang terjadi bukan dialog, tapi monolog. Masing-masing kelompok membuat standar ganda. Standar normatif untuk agamanya sendiri dan standar historis untuk menjustifikasi agama lain. Dengan begitu dialog hanya berkutat 
pada persoalan konsep yang bersifat normatif dan tekstual saja. Belum menyentuh pada persoalan praksis sehari-hari.

Ketika praksis Islam melalui jalur pendidikan telah memperlihatkan hasilnya yakni terbentuknya manusia beradab, maka yang dipikitkan berikutnya soal jalinan kerjasama dan persaudaraan antaragama sebagai komunitas masyarakat berbangsa. Persaudaraan diperlukan untuk mengubah perbedaan menjadi pangkal sikap hidup positif, seperti keterpanggilan diti untuk berlomba beramal kebajikan. ${ }^{10}$ Itu penting karena persaudaraan dan perjumpaan antaragama semakin mendesak digalakkan tatkala masyarakat menghadapi persoalan kebangsaan yang sama yang melibatkan semua warga masyarakat tanpa membeda-bedakan bendera agama. Karena itu semua agama harus bersinergi menjalankan fungsi transformatifnya. Ini sebuah kewajiban mengingat agama adalah realitas yang imanen dan isu kemanusiaan apapun bentuknya menjadi problem yang harus dijawab oleh agama.

Persoalannya proses membangun sinergi antaragama saat ini kerap menghadapi kendala. Meski kamus teologi agama-agama banyak memberi ruang kosakata bagi tumbuhnya simpul persamaan sebagai titik ternu (common platform), namun jejaring soliditas antaragama masih rapuh karena intensitas perjumpaan hanya melibatkan para tokoh agama. Berbekal nilai keadaban yang dibentuk oleh Islam melalui instrumen pendidikan, maka perjumpaan dan relasi antaragama selayaknya tidak lagi bersifat elitis. Gerakan itu tidak akan memiliki daya dobrak karena di tingkat elite kharisma tokoh agama mengalami reduksi legitimasi di mata pemerintah.

Masih segar dalam ingatan ketika para tokoh agama bersikap kritis membeberkan sejumlah kebohongan yang dilakukan pemerintah. Alih-alih metespons kritik itu dengan bijak, pemetintah justru reaktif dan menuding tokoh agama laksana burung gagak hitam pernakan bangkai. Segala hal yang berbau kritik, seruan moral dan somasi dari tokoh agama cenderung dipahami sebagai gerakan politik untuk menggulingkan kekuasaan.

10 Nurcholish Madjid, Masyarakat Religius; Membumikan Nilai-Nilai Islam dalam Kebidupan Masyarakat, (Jakarta: Paramadina,2004),hal.41. 
Karena itu, memperkuat basis Islam dalam perjuangan meretas keadabar Indonesia yang multikultural harus ada keterlibatan koeksistensial agama-agam: dari akar rumput sehingga menjaga martabat kemanusiaan bukan hanya tuga: elit agama, tapi menjadi keharusan bersama umat beragama.

\section{E. Penutup}

Meretas keadaban masyarakat Indonesia multikultural tidak bisa dilepaskat dari kontribusi Islam sebagai agama yang dipeluk mayoritas masyarakat Berbagai persoalan kebangsaan yang mendera kita saat ini sedikit banyal dipengaruhi nilai keadaban umat Islam yang mulai luntur. Karena itu untul mengasah kembali nilai kesucian itu diperlukan rumusan dan langkah konkri sehingga ajaran universal Islam tidak hanya memiliki pesona di tataran kajiar ilmiah, tetapi juga memiliki makna penting pada ranah praksis sosial.

Pendidikan adalah kanal yang tepat untuk menanamkan nilai Islam yan toleran dan beradab. Dalam pendidikan keadaban bisa dibangun melalu komunitas kecil hingga akhimya menjadi karakter dan budaya masyarakat kita Ketika pendidikan menghasilkan tipe manusia inklusif dan toleran, pokol berikutnya adalah menjalin kejjasama antaragama dalam bingkai kebangsaan. It penting karena masyarakat menghadapi persoalan kebangsaan yang sama tanp: membeda-bedakan bendera agama. Sehingga memandang krisis keadabar sebagai masalah bersama yang harus disikapi secara bersama-sama.

\section{DAFTAR PUSTAKA}

Fauzi, Achmad.2011. Robobnya Keadaban Kita, Harian Kompas, 17 September.

Fauzi, Achmad.2012. "Syiah Sampang Versus Syiar Kebencian", Korar Tempo, 6 Januari.

Madjid, Nurcholish. 2004. Masyarakat Religius; Membumikan Nilai-Nilai Islan dalam Kebidupan Masyarakat, Jakarta: Paramadina. 
Rais, Amien, dkk.1997. Tidak Ada Negara Islam (Surat-surat Politik Nurcbolish Madjid - M. Roem), Jakarta: Djambatan.

Sumartana, Th. dkk. 2001. Pluralisme, Konflik, dan Perdamaian, Yogyakarta: Interfidei.

The Wahid Institute.2011. Laporan Kebebasan Beragama 2011 The Wabid Instituie, dalam http://www.wahidinstitute._Beragama_2011_The_ Wahid_Institute.

Toynbee, Amold. 1948. Civilization on Trial, Oxford: Oxford University Press.

Wahid, Abdurrahman .1999. Tuban Tidak Perlu Dibela, Yogyakarta : LKiS. 
350 Millab Vol. XI, No. 2, Februari 2012 